University of Nebraska - Lincoln

DigitalCommons@University of Nebraska - Lincoln

Faculty Publications, Department of Mathematics

Mathematics, Department of

2-1961

\title{
A NOTE ON HAUSDORFF SEPARATION
}

Edwin Halfar

University of Nebraska - Lincoln

Follow this and additional works at: https://digitalcommons.unl.edu/mathfacpub

Part of the Mathematics Commons

Halfar, Edwin, "A NOTE ON HAUSDORFF SEPARATION" (1961). Faculty Publications, Department of Mathematics. 46.

https://digitalcommons.unl.edu/mathfacpub/46

This Article is brought to you for free and open access by the Mathematics, Department of at DigitalCommons@University of Nebraska - Lincoln. It has been accepted for inclusion in Faculty Publications, Department of Mathematics by an authorized administrator of DigitalCommons@University of Nebraska - Lincoln. 


\section{A NOTE ON HAUSDORFF SEPARATION}

\section{EDWIN HaLfar, University of Nebraska}

The examples usually given as instances of topological spaces that have $T_{1}$-separation but not $T_{2}$-separation (Hausdorff) also have the property that some compact subset is not closed. This with the classic result concerning closedness of compact subsets of a Hausdorff space suggests the question of the equivalence of Hausdorff separation and the condition that the class of compact subsets be a subclass of the class of the closed subsets of a given space. The following is a simple result of this type and may be of some use in an introductory course in point set topology.

THEOREM. If $X$ is a space satisfying the first axiom of countability, then a necessary and sufficient condition that $X$ be a Hausdorff space is that the class of compact subsets of $X$ be a subclass of the class of closed subsets of $X$.

Only the sufficiency need be considered here.

Since points are compact, it is immediate that $X$ must be at least $T_{1}$. Also it can be assumed that the neighborhood base $\left\{V_{n} / n=1,2, \cdots\right\}$ at each point is such that $V_{n} \subseteq V_{m}, n \geqq m$. Suppose there exist points $x$ and $y$ such that there are no disjoint pairs of neighborhoods of $x$ and $y$ respectively. Then a sequence $\left\{x_{n} / n=1,2, \cdots\right\}$ may be selected by choosing each $x_{n}$ in the intersection of the $n$th sets of the neighborhood bases of $x$ and $y$. The set $\left\{x_{n} / n=1,2, \cdots\right\}$ $\cup[x]$ is compact but is not closed since $y$ is an accumulation point.

That the assumption of a local countable base or some other restriction is necessary is seen from the following example.

Let $X$ be an uncountable set with a topology such that a set is open if and only if it is $X$, the null set or the complement of a countable set. The space is not Hausdorff and does not satisfy the first axiom of countability. However the only compact sets are finite sets and hence closed. 